https://doi.org/10.11646/phytotaxa.375.4.4

\title{
Vera-duthiea zebrina (Asparagaceae, Scilloideae), a new species from eastern South Africa, and a first genus record for southern Africa
}

\author{
MARIO MARTÍNEZ-AZORÍN ${ }^{1 *}$, NEIL R. CROUCH ${ }^{2,3}$ \& MANUEL B. CRESPO ${ }^{1}$ \\ ${ }^{I}$ dCARN (Depto. Ciencias Ambientales y Recursos Naturales) and CIBIO (Instituto Universitario de la Biodiversidad), Universidad de \\ Alicante, P. O. Box 99,E-03080 Alicante,Spain; e-mail:mmartinez@ua.es \\ ${ }^{2}$ Biodiversity Research, Assessment \& Monitoring, South African National Biodiversity Institute, P.O. Box 52099, Berea Road 4007, \\ South Africa; e-mail: n.crouch@sanbi.org.za \\ ${ }^{3}$ School of Chemistry and Physics, University of KwaZulu-Natal, 4041 South Africa \\ "author for correspondence
}

\begin{abstract}
In the course of revising the subfamily Urgineoideae of the Hyacinthaceae it became evident, based on molecular and morphological data, that some plants usually named 'Drimia indica' from northeastern South Africa represent rather an undescribed species of Vera-duthiea. This is the first record of this genus occurring in southern Africa. The new species $(V$. zebrina) was collected and illustrated some 50 years ago, but never validly published. We here provide data on its morphology, ecology, and distribution.
\end{abstract}

Keywords: Drimia indica, Hyacinthaceae, taxonomy, Urgineoideae, Vera-duthiea

\section{Introduction}

Although generic circumscriptions within the Hyacinthaceae subfamily Urgineoideae (= Scilloideae tribe Urgineae) have been contentious in recent decades (see Martínez-Azorín et al. 2013, 2017, Crouch \& Martínez-Azorín 2015 for context), an ongoing revision of the Urgineoideae (M. Martínez-Azorín and collaborators, in preparation) is resolving relationships. Our phylogenetic studies (not shown) include three plastid regions (trn L-F, matK, $y c \mathrm{f}$ ) and a nuclear one (Agt1) and more than 250 samples covering almost the entire subfamily distribution range. Our findings strongly support a multi-generic treatment in Urgineoideae, with taxa arranged in several well-supported clades that correspond to distinct traditionally accepted genera, and/or clades which show unique syndromes of morphological characters and biogeography. This molecular and morphological work has informed several recent genera descriptions, including Mucinaea Pinter et al. (2013: 296), Sagittanthera Martínez-Azorín et al. (2013: 46), Aulostemon Martínez-Azorín et al. (2017: 288), Austronea Martínez-Azorín et al. (2018a: 105), Zingela Crouch et al. (2018: 36) and Iosanthus Martínez-Azorín et al. (2018b).

Speta (2001) described Duthiea Speta (2001: 170) based on genetic and morphological studies, and included three species occurring from central to north-western Africa: D. senegalensis (Kunth 1843: 334) Speta (2001: 170), the type of the genus, D. macrocarpa (Stedje 1987: 664) Speta (2001: 170) and D. noctiflora (Battandier \& Trabut 1894: 505) Speta (2001: 170). This genus is characterised by the imbricate bulb scales, proteranthous leaves, patent pedicels, perigone slightly connate at the base, nocturnal flowers, white and thin filaments, style broadened at apex, ovoid ovary, and flattened and black seeds (Speta 2001). However, prior publication of both Duthiea Hackel (1896: 200) and Duthiea Manza (1937: 48) renders Speta's genus illegitimate. To rectify this situation, Speta (2016) published Vera-duthiea Speta (2016: 154) as a nom. nov. for his Duthiea and presented the combinations V. senegalensis (Kunth 1843: 334) Speta (2016: 155), V. macrocarpa (Stedje 1987: 664) Speta (2016: 155) and V. noctiflora (Battandier \& Trabut 1894: 505) Speta (2016: 155). The genus Vera-duthiea had not been known to extend into southern Africa until our molecular analyses revealed an undescribed species from South Africa, earlier misidentified as Drimia indica (Roxburgh 1832: 147) Jessop (1977: 272). 
Approximately 50 years ago, Elsa Pooley gathered two urgineoids at the Ndumo Game Reserve in northeastern Zululand in South Africa (Pooley $127 \mathrm{NU}$ and Pooley $661 \mathrm{NU}$ ), which she illustrated in watercolour (Fig. 1B-C in Crouch et al. 2018). A contemporaneous Hyacinthaceae taxonomist (Mrs A.A. Mauve [=A.A. Obermeyer], based at PRE) considered the two specimens to represent different varieties of the same species, which she closely allied to Urginea indica (Roxburgh 1832: 147) Kunth (1843: 333) [= Drimia indica]. Mauve proposed in schedae the names "Urginea zebrina Oberm. n. sp. ms." for Pooley 127 (NU) and "Urginea zebrina Oberm. $n$. sp. var. multiflora Oberm. var. nov. ms." for Pooley 661 (NU). She herself encountered Vera-duthiea (Fig. 1A) whilst botanizing the southeastern Kruger National Park during December of 1969, observing plants in flower and fruit east of Muntshe Hill (Mauve 4823, PRE; Fig. 1B). Mauve initially considered her find to be new, immediately organizing its illustration by Rhona Collett for a description in the journal Bothalia (Fig. 1B). However, her opinion was soon swayed by Dr D. Killick, then the South African Botanical Liaison Officer at Kew, who submitted that it was conspecific with "Urginea indica", based on K material viewed by him (correspondence from Mauve to Pooley dated 22 July 1970; ref. B 67).
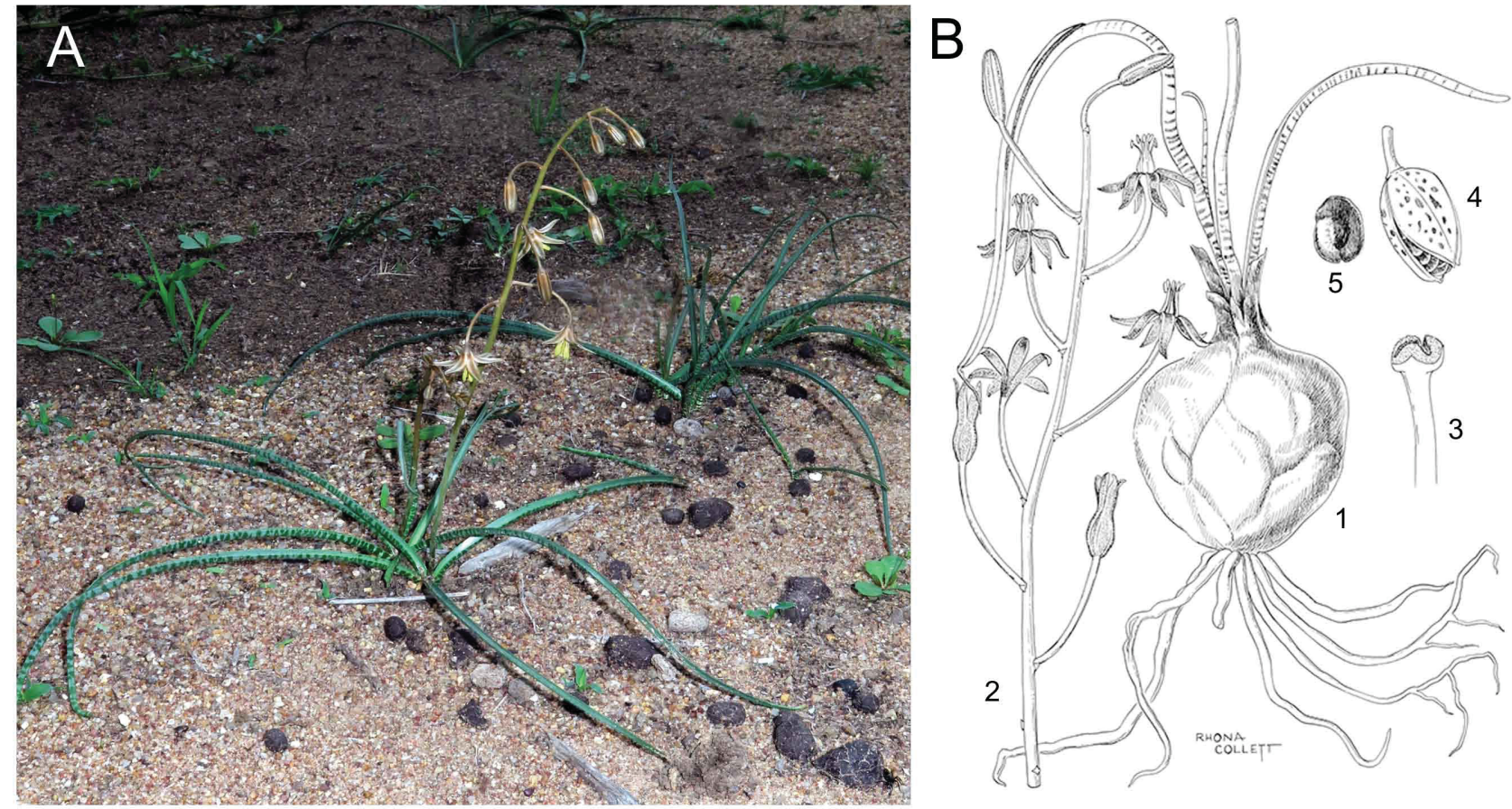

FIGURE 1. Vera-duthiea zebrina Mart.-Azorín, N.R.Crouch \& M.B.Crespo. A. Plant in flower in moist open grassland, Ndumo Game Reserve, KwaZulu-Natal Province, South Africa (Photograph N.R. Crouch); B. Line illustration by R. Collett based on Mauve 4823 (PRE): 1. Bulb and leaves $(\times 0.5) ; 2$. Raceme $(\times 0.5)$; 3. Style and stigma $(\times 2)$; 4. Capsule $(\times 0.5)$; 5. Seed $(\times 1)$.

As Mauve published neither of these two in schedae names, subsequent researchers (e.g. Jessop 1977) supposed Drimia indica to occur in the Flora of southern Africa (FSA) region. Nonetheless, Pooley (1978) recognised that her Ndumo collections represented two taxa that differed in several respects, most notably in leaf and bulb form, in the number, size and orientation of flowers, in floral scent and opening times, and in habitat preferences. As detailed by Crouch et al. (2018), Pooley 661 (NU) represents a distinct new genus described as Zingela pooleyorum Crouch et al. (2018: 36). The second collection Pooley 127 (NU) belongs to Vera-duthiea based on its morphology as here detailed, and its phylogenetic relationships (M. Martínez-Azorín and collaborators, in preparation).

Our phylogenetic studies include several samples of Drimia indica from India and Thailand which form a wellsupported clade corresponding to Indurgia Speta (2001: 169), a genus endemic to southwestern Asia. Moreover, the Indurgia clade is placed far from Zingela, Thuranthos Wright (1916: 233) and Vera-duthiea clades, noteworthy in this context as some species of Indurgia are superficially similar in vegetative or sexual form to Vera-duthiea species. The taxon represented by Pooley 127 (NU) is morphologically distinct from all described Indurgia species such that Drimia indica is accordingly now excluded from the South African plant species catalogue.

As the name Urginea zebrina Oberm. (in scheda) is not validly published, we here recognise at species rank the taxon represented by Pooley 127 (NU), and place it in Vera-duthiea. This placement is based on the following characters: bulb compact; leaves synanthous, narrowly canaliculated, with dark green maculations below that merge to form distinct transverse bands along the entire length, especially at the base; lax raceme with up to 13 flowers, pedicels 20-30 mm long; bracts minute and inconspicuous at anthesis; bracteoles absent; flowers brown, nodding, 
nocturnal, strongly scented; stamens curved; filaments free, incurved along the lower half, almost connivent to style in middle section and spreading distally, thickened, terete in cross-section, proximally attenuated to only $0.3 \mathrm{~mm}$ wide; anthers not circinnate; ovary ovate with narrowly clavate, deflexed style and subcapitate stigma; and capsule ovate with conspicuous chestnut markings. We describe Vera-duthiea zebrina to accommodate this novelty and provide a complete description with data on its biology, ecology and distribution.

\section{Description of the new species}

Vera-duthiea zebrina Mart.-Azorín, N.R.Crouch \& M.B.Crespo sp. nov. (Figs. 1 \& 2).

-Urginea zebrina Oberm. in scheda

It differs from both $V$. senegalensis and $V$. macrocarpa in its synanthous rather than hysteranthous phenology, and its filaments that narrow considerably at their base rather than broaden substantially. The leaves of $V$. zebrina are broadest at the base and are abaxially maculate along their entire length, whereas those of $V$. macrocarpa are broadest in their middle and spotted only towards the base. Vera-duthiea noctiflora differs by the unspotted, distinctly coiled, proteranthous leaves and its much smaller flowers.

Type:-SOUTH AFRICA. KwaZulu-Natal, Bela Vista (2632CD): Ndumo [Ndumu] Hill, Ndumo [Ndumu] Game Reserve, 4 November 1968, E.S. Pooley 127 (holotype, NU!, isotype, NH!).

Herbaceous, perennial, bulbous plant. Bulb hypogeal, compact, 5-6 $\times 4.5-5 \mathrm{~cm}$, turbinate to subglobose, solitary to occasionally multiplying through division, scales white, thickly succulent, sometimes imbricate; basal plate narrow, to $1 \mathrm{~cm}$ in diameter, roots whitish-cream, thickened, contractile, ca. $2 \mathrm{~mm}$ in diameter. Leaves 2-5(-7), synanthous, bright to mid green, unspotted adaxially and with dark green maculations abaxially that merge to form distinct transverse bands along the entire length, especially prominent at the base, glabrous, narrowly linear, tapering gradually towards an acute apex, deeply canaliculate, rounded abaxially, arching, spreading, 10-30 cm long, 4-5 mm wide when incurved and 8-9 $\mathrm{mm}$ wide when flat (broadest at the base). Inflorescence presented above the spreading leaves, racemose, the peduncle erect to leaning, 25-38 cm long, greenish-brown, slightly mottled at base, covered with a light white bloom, the raceme lax, 4-10 cm long, with 5-13 flowers, erect to arching; pedicels of flowers 20-30 mm long at anthesis, arching down, purple-brown, with whitish bloom, elongating and arching up in fruit. Bracts very small, ca. $2 \mathrm{~mm}$ long, clasping, deltate-triangular, acute, greenish-brown with a membranous white margin, spurs as long as blade, flattened, appressed, those from the middle and upper parts of the inflorescence showing very short or inconspicuous spurs; bracteoles absent. Flowers short-lived, dark brown pentacyclic, trimerous, stellate, nodding, opening in the early evening and closing during night. Tepals 6 , biseriate, almost free from the base, outer tepals lanceolate, 13-14 $\times$ 4.0-4.5 mm, with acute apex, inner tepals lanceolate, $13-14 \times 3.9-4.2 \mathrm{~mm}$, with acute apex; tepals adaxially carneous brown with lighter margins and an olive-brown median stripe, carneous brown abaxially with olive-castaneous median stripe. Stamens 6, curved; filaments free, adnate to tepals for ca. $1 \mathrm{~mm}$, incurved along the lower half, almost connivent to style in middle section and spread distally, thickened, terete in cross-section, ca. $10 \times 0.7 \mathrm{~mm}$, proximally attenuated in lower $1 / 4$ to only $0.3 \mathrm{~mm}$ wide; anthers narrowly oblong, carneous, near-basifixed, ca. $3 \times 0.8 \mathrm{~mm}$ pre dehiscence, dehiscing longitudinally along the whole length. Ovary ovate, greenish above and white at base, shallowly 3 -angled, ca. $4.5 \times 3.2 \mathrm{~mm}$. Style well differentiated, white, round in cross-section, narrowly clavate, becoming gradually broader distally, deflexed from lower part to distally approach the spreading filaments, ca. $8 \times 0.6 \mathrm{~mm}$ proximally-1.1 mm distally. Stigma slightly overtopping anthers, subcapitate, shortly papillate. Immature capsule light cream, basally with conspicuous chestnut markings and green along the septal nectaries, triloculate, loculicidal, ovate, 13-14 × 8-9 mm. Seeds flattened, subelliptic, with prominent central embryo and broad wings, ca. $6.5 \times 4 \mathrm{~mm}$, black (Figs. 1-2).

Etymology:-zebrina, for the characteristic dark-green banding of the abaxial leaf surfaces.

Biology:-Plants grow as small, often dense clumps which have leaves fully mature when the erect to leaning few-flowered inflorescences are produced. Flowering occurs in early to mid-summer, October through January in southern Africa. The inflorescences present few flowers which last only one night. The flowers open from $17 \mathrm{~h} 00$ until late into the night; they are strongly scented, emitting a seminiferous or yeasty odour that is presumed to attract moths.

Habitat:-At Ndumo Game Reserve, plants grow in full sun at the edge of pools and pans (Fig. 1A) and in seasonally inundated short grassland at an elevation of ca. 35-85 m, on both clay and sandy soils in Western Maputaland Sandy Bushveld (SVl 19) and Western Maputaland Clay Bushveld (SVl 20) within the Savanna Biome (Rutherford et al. 2006). In the Kruger National Park (Mpumalanga Province) plants similarly grow in open moist vlei areas, but at a slightly higher elevation of ca. $240 \mathrm{~m}$. 


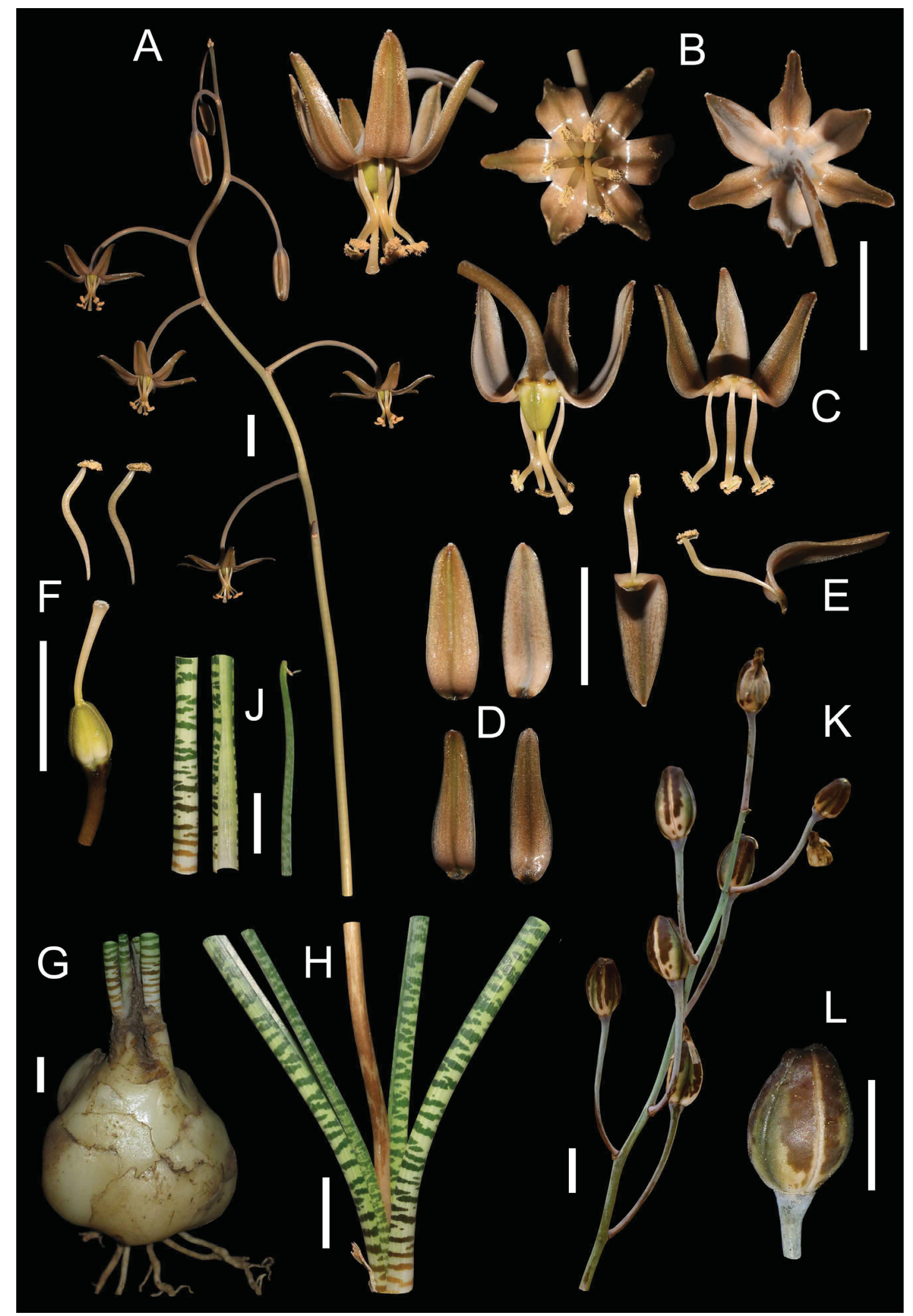

FIGURE 2. Vera-duthiea zebrina Mart.-Azorín, N.R.Crouch \& M.B.Crespo plant in flower in cultivation from Ndumo Game Reserve, KwaZulu Natal Province, South Africa, on 28 June 2018. A. Inflorescence; B. Flower in lateral, apical and dorsal views; C. Dissected flower in lateral view; D. Tepals, outers above and inners below, lateral views; E. Tepals with stamens, dorsal and lateral views; F. Gynoecium and stamens, lateral views; G. Bulb with portion of leaves, lateral view; H. Basal part of leaves and peduncle; J. Details of the canaliculate leaves (left) and apex (right); K. Infructescence; L. Immature capsule, lateral view. Scale bars: $1 \mathrm{~cm}$. 
Distribution:- The new species is known so far only from the northernmost part of KwaZulu-Natal along the Mozambique border, and from Kruger National Park, both sites within South Africa and some $210 \mathrm{~km}$ distant (Fig. 3). The likelihood of $V$. zebrina occurring also in southern Mozambique is high given the proximity of both known localities to borders with that country; the most recent flora checklist for Mozambique (Da Silva et al. 2004) does not list ' $D$. indica'. This species may yet be identified from the nearby Kingdom of eSwatini (formerly known as Swaziland).

Taxonomic relationships:-Three species of Vera-duthiea were accepted by Speta (2001, 2016): Vera-duthiea senegalensis, $V$. macrocarpa and $V$. noctiflora. The new species clearly differs from all previously accepted species in the genus by the synanthous leaves that are maculated abaxially for their entire length showing a zebrine pattern, whilst the other species present hysteranthous or proteranthous leaves which are only sometimes maculate basally. Moreover, filaments of both $V$. senegalensis and $V$. macrocarpa broaden substantially at their base whilst those of $V$. zebrina narrow distinctly. Vera-duthiea noctiflora is unique in the subfamily in having coiled leaves and produces much smaller flowers than V. zebrina. Further, the four species have disjunct distribution ranges: $V$. noctiflora is endemic to the arid regions of southwestern Morocco, $V$. senegalensis is known only from western central Africa, $V$. macrocarpa (= Ornithogalum laikipiense Newton 2003: 18) occurs in East Africa, and V. zebrina is known from the northeastern regions of southern Africa. Other genera closely related to Vera-duthiea are Indurgia, Thuranthos, and Zingela. However, Thuranthos and Zingela show bulbs comprised of loose, cucullate, pedicellate scales, and leaves which are prominently keeled, among other characters, whilst bulbs of Vera-duthiea are compact and their leaves are not distinctly keeled. Members of Indurgia are restricted in range to southwestern Asia, and although superficially similar in flower morphology to Vera-duthiea zebrina, they differ by their unspotted, proteranthous leaves, among other characters.

Additional material studied (paratypes):-SOUTH AFRICA. Mpumalanga: Acornhoek (2431), East of Muntshe Hill, Kruger National Park (-DD), 3 December 1969, line illustration prepared from A.A Mauve 4823 (PRE!); KwaZulu-Natal: Bela Vista (2632), Ndumo Game Reserve near gate area, in seasonally inundated grassland (-CC), elev. 300 ft, 5 November 1969, E.J. Moll 4309 (NH!, PRE!); Bela Vista (2632), Ndumo Game Reserve to southwest of Shokwe Pan on road to Red Cliffs (-CC), elev. 45 m, 16 November 2016 (in flower and immature fruit), N.R. Crouch s.n. (v.v.); Bela Vista (2632), Ndumo Game Reserve, alongside road $3.5 \mathrm{~km}$ northwest of main gate to reserve (-CC), elev. $40 \mathrm{~m}, 16$ November 2016 (in flower and immature fruit), N.R. Crouch s.n. (v.v.).

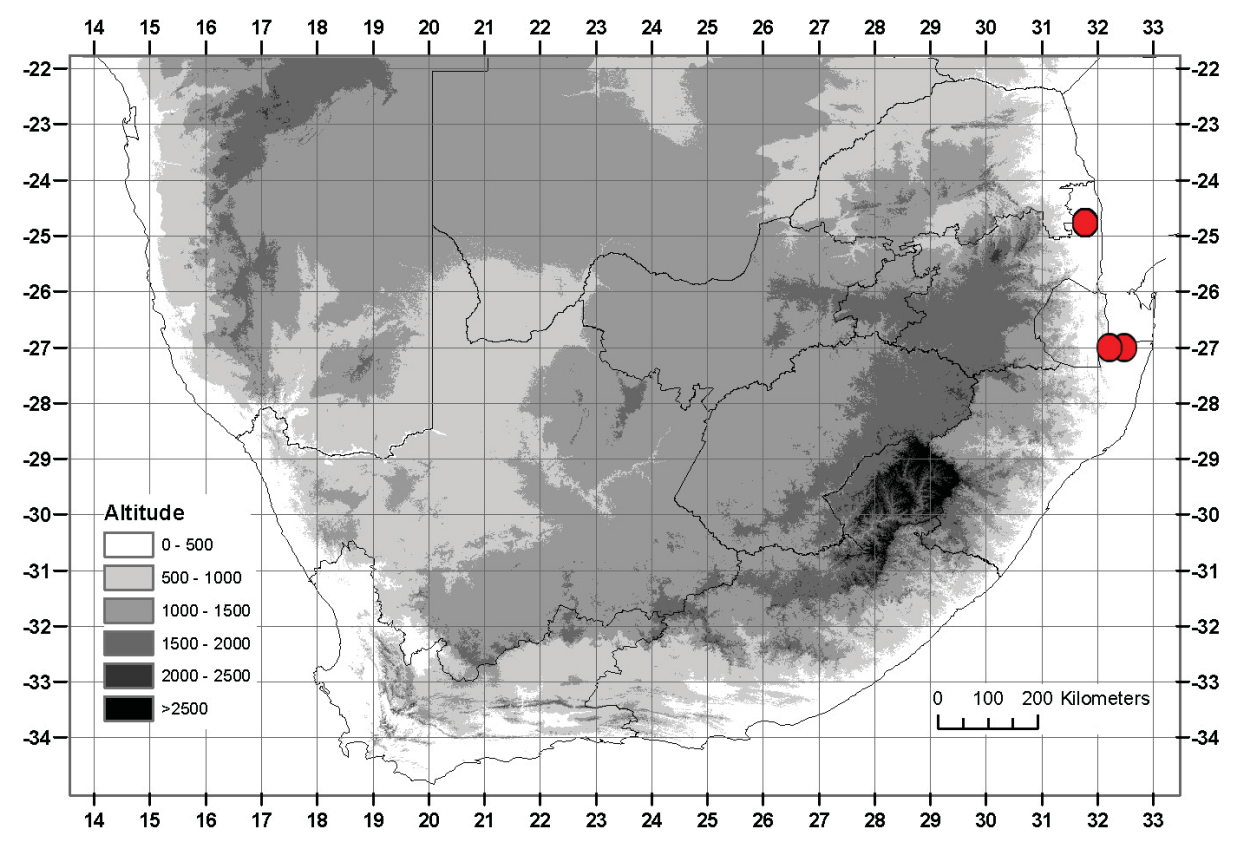

FIGURE 3. Known distribution of Vera-duthiea zebrina Mart.-Azorín, N.R.Crouch \& M.B.Crespo in eastern South Africa. 


\section{Acknowledgements}

This work was partly supported by H2020 Research and Innovation Staff Exchange Programme of the European Commission, project 645636: 'Insect-plant relationships: insights into biodiversity and new applications' (FlyHigh). We thank the curators of the herbaria cited in the text for access to specimens and Ezemvelo-KZN Wildlife for a collecting permit (No. OP 3969/2015). Elsa Pooley kindly provided archival correspondence relating to Vera-duthiea at both Ndumo GR and Kruger National Park.

\section{References}

Battandier, J.A. \& Trabut, L. (1894) Description d'une nouvelle espèce du genre Urginea Steinheil. Compte Rendu de l'Association Francaise pour l'Avancement des Sciences 1893 (Séance 22, part. 2, Besançon): 505-506.

Crouch, N.R. \& Martínez-Azorín, M. (2015) Drimia edwardsii (Asparagaceae, Scilloideae), a new urgineoid species from the Mkhomazi River Valley of eastern South Africa. Phytotaxa 195: 135-144.

https://doi.org/10.11646/phytotaxa.195.2.2

Crouch, N.R., Martínez-Azorín, M., Crespo, M.B., Pinter, M. \& Alonso-Vargas, M.A. (2018) Zingela (Asparagaceae, Scilloideae), a distinct new urgineoid genus from KwaZulu-Natal, South Africa. Phytotaxa 371: 33-41.

https://doi.org/10.11646/phytotaxa.371.1.4

Da Silva, M.C., Izidine, S. \& Amude, A.B. (2004) A preliminary checklist of the vascular plants of Mozambique. In: Southern African Botanical Diversity Network Report No. 30. SABONET, Pretoria, 183 pp.

Hackel, E. (1896) Duthiea, novum Graminearum genus. Verhandlungen der Kaiserlich-Königlichen Zoologisch-Botanischen Gesellschaft in Wien 45: 200-203.

Jessop, J.P. (1977) Studies in the bulbous Liliaceae in South Africa 7. The taxonomy of Drimia and certain allied genera. Journal of South African Botany 43 (4): 265-319.

Kunth, K.S. (1843) Enumeratio plantarum omnium hucusque cognitarum, secundum familias naturales disposita, adjectis characteribus, differentiis et synonymis. Vol. 4. J.G. Cottae, Stutgardiae et Tubingae, 752 pp.

Manza, A.V. (1937) The genera of the Articulated Corallines. Proceedings of the National Academy of Sciences of the United States of America 23: 44-48. https://doi.org/10.1073/pnas.23.2.44

Martínez-Azorín, M., Crespo, M.B., Alonso-Vargas, M.A., Dold, A.P., Pinter, M. \& Wetschnig, W. (2018a) Austronea (Asparagaceae, Scilloideae), a new genus from southern Africa, including the description of seven new species. Phytotaxa 365: 101-129. https://doi.org/10.11646/phytotaxa.365.2.1

Martínez-Azorín, M., Crespo, M.B., Dold, A.P., Wetschnig, W., Pinter, M., Pfosser, M. \& van Jaarsveld, E. (2013) Sagittanthera (Hyacinthaceae, Urgineoideae), a new buzz pollinated genus from the Eastern Cape Province of South Africa. Phytotaxa 98: 43-54.

https://doi.org/10.11646/phytotaxa.98.2.2

Martínez-Azorín, M., Crespo, M.B., Pinter, M., Slade, J.M. \& Wetschnig, W. (2018b) Iosanthus (Hyacinthaceae subfam. Urgineoideae), a new genus from southern Africa to include Ornithogalum toxicarium and its removal from Ornithogaloideae. Plant Biosystems. [in press]

Martínez-Azorín, M., Crespo, M.B., Pinter, M. \& Wetschnig, W. (2017) Aulostemon (Asparagaceae, Scilloideae), a new genus from South Africa. Phytotaxa 321: 287-293.

https://doi.org/10.11646/phytotaxa.321.3.6

Newton, L.E. (2003) A new Ornithogalum from Kenya. The Plantsman 2: 18-20.

Pinter, M., Crespo, M.B., Ilg, I., Luidold, A.K., Martínez-Azorín, M., Müller-Doblies, U., Müller-Doblies, D., Pfosser, M. \& Wetschnig, W. (2013) Mucinaea (Hyacinthaceae-Urgineoideae), a remarkable new genus from Namaqualand (Northern Cape Province, South Africa). Phyton 53: 289-304.

Pooley, E.S. (1978) Checklist of the flora of Ndumu Game Reserve, north-eastern Zululand. Journal of South African Botany 44 (1): $1-54$.

Roxburgh, W. (1832) Flora Indica 2. Thacker \& co., Calcutta, 691 pp.

Rutherford, M.C., Mucina, L., Lötter, M.C., Bredenkamp, G.J., Smit, J.H.L., Scott-Shaw, C.R., Hoare, D.B., Goodman, P.S., Bezuidenhout, H., Scott, L., Ellis, F., Powrie, L.W., Siebert, F., Mostert, T.H., Henning, B.J., Venter, C.E., Camp, K.G.T., Siebert, S.J., Matthews, 
W.S., Burrows, J.E., Dobson, L., Van Rooyen, N., Schmidt, E., Winter, P.J.D., Du Preez, P.J., Ward, R.A., Williamson, S. \& Hurter, P.J.H. (2006) Savanna Biome. In: Mucina, L. \& Rutherford, M.C. (Eds.) The vegetation of South Africa, Lesotho and Swaziland. South African National Biodiversity Institute, Pretoria, pp. 439-567.

Speta, F. (2001) Die echte und die falsche Meerzwiebel: Charybdis Speta und Stellarioides Medicus (Hyacinthaceae), mit Neubeschreibungen und Neukombinationen im Anhang. Stapfia 75: 139-176.

Speta, F. (2016) Substitution of an illegitimate generic name in Hyacinthaceae, and validation of names of already described species in Ornithogalum (Hyacinthaceae) and Pinguicula (Lentibulariaceae). Phyton (Horn) 56: 153-159.

Stedje, B. (1987) A revision of the genus Drimia (Hyacinthaceae) in East Africa. Nordic Journal of Botany 7: 655-666. https://doi.org/10.1111/j.1756-1051.1987.tb02034.x

Wright, C.H. (1916) Diagnoses africanae: LXIX. Bulletin of Miscellaneous Information, Royal Botanic Gardens, Kew 1916: $229-235$. https://doi.org/10.2307/4114331 